\title{
Molecular and Phenotypic Characterization of Some Antimicrobial Resistance Genes in Escherichia coli Isolated from Human and Broiler Chickens
}

\author{
Mohamed Elmahdy Shehata ${ }^{1}$, Gamal Mohamed EL-Sherbiny ${ }^{1}$, \\ Amira Hussainy Mohamed ${ }^{2}$ and Hesham Mohamed Shafik ${ }^{2}$ \\ ${ }^{1}$ Department of Botany and Microbiology, Faculty of Science (boys), Al-Azhar University, \\ Madient Nasr, 11884 Cairo, Egypt \\ ${ }^{2}$ Department of Botany, Faculty of Science, Port Said University, Port Said, Egypt \\ *Corresponding author
}

\section{Keywords \\ Escherichia coli, poultry, antimicrobial resistance genes TEM (Beta-lactam) gene.}

\section{Article Info}

Accepted:

28 November 2016

Available Online:

10 December 2016

\section{A B S T R A C T}

Antimicrobial resistance is an issue of global concern and threats both animal and human health worldwide. The current research was carried out to characterize the genetic characteristics of antibiotic resistance in Escherichia coli isolates from hospitalized patients and fecal E. coli of broiler chickens. A total of $97 \mathrm{E}$. coli strains isolated from urine specimens of hospitalized patients and fecal samples of broiler chickens were subjected to bacteriological and biochemical examination. Samples were analyzed by agar disc diffusion to determine their susceptibility patterns to 13 antimicrobial agents. Ten of different resistant pattern strains were screened by molecular methods to detect 10 resistance genes. All the E. coli isolates showed high resistance to multiple drugs. The resistance pattern of all isolates was most frequently observed against Ampicillin $78.4 \%$, Trimethoprim/sulfameth $71.1 \%$, Streptomycin $75.3 \%$, AmoxicillinSulbactam $69.1 \%$ and Tetracyciln $65 \%$, but less frequently with Levofloxacin 11.3\%, Ceftriaxone $26.8 \%$ and Ciprofloxacin 33\%. Strains of E. coli from human were highly resistant to Ampicillin $72.7 \%$ but the highest level of antibiotic resistance in broiler isolates recorded against Amoxicillin-Sulbactam 85.7\%. However, the lowest level of antimicrobial resistant recorded with Levofloxacin either in human $12.7 \%$ or in broiler $9.5 \%$. Ten E. coli isolates (five for each human and broiler) with different resistance pattern were selected and screened by molecular methods for resistance genes. The sulI (sulfonamide), tetA (Tetracycline) and $t e t B$ resistance encoding genes were detected in all the tested isolates $(100 \%)$ but no one of tested E. coli isolates contained TEM (Beta-lactam) gene. The antibiotic resistance genes $O X A, S H V, d h f r V, d h f r I, c m l A$ and catl were detected in both human isolates and animal isolates. E. coli from both humans and broiler chickens recorded resistance to the commonly used antibiotics. Moreover, multidrug resistance to $E$. coli isolated from broiler samples was higher in frequency than those isolated from clinical specimens. Therefore, regular monitoring and regulated use of antimicrobial in broiler farms should be encouraged. 


\section{Introduction}

Increasing rates of antimicrobial resistance have become a worldwide problem for both human and animal health. It is responsible for the increasing incidence of debilitating and lethal diseases (World Health Organisation (WHO), 2015). Antimicrobial agents are nowadays used, not just for human therapy, but also for farming purposes such as the prophylactic and growth-promoting use in agriculture, aquaculture, and horticulture (Ferber, 2003). Unfortunately, the selective pressure caused by the intensive use and misuse of antimicrobial agents in human, veterinary medicine, livestock, aquaculture, agriculture and food technology, associated with several mechanisms for bacteria genetic transfer is probably the main causes of the emergence and spread of resistance in different bacterial groups (Authier et al., 2006; Werner et al., 2008).

The spread of antibiotic-resistant bacteria in the environment are dependent on the presence and transfer of resistance genes among microorganisms, mutations, and selection pressure to keep these genes in a population (Cabello, 2006). These genes do not recognize or respect phylogenetic, ecological, or geographical borders. Therefore, resistance resulting in one ecological niche or species may be able to spread with ease to another niche or species (Okeke et al., 2001).

Bacteria have developed different resistance mechanisms to overcome the antibiotics used against them. The genes encoding these defense mechanisms are located either on the bacterial chromosome or on extrachromosomal plasmids. These genes can be transferred vertically among bacteria of different genera and families or horizontally between different bacterial species within the same genus or family
(Nikolich et al., 1994). Horizontal gene transfer occurs via mobile genetic elements, such as plasmids, bacteriophage, transposons and gene cassette in integrons. Briefly, it is well known that the mechanism of antimicrobial resistance could happen with enzymatic inactivation, altered receptors or by altering the antibiotic transport mechanism (Koneman et al., 1997).

Because of heavy use of antimicrobial agents in food animal production, bacteria originating from food animals frequently carry resistance to a range of antimicrobial agents, including those commonly used in humans. These agents exert a selection pressure not only on pathogenic bacteria, but also on commensal microorganisms of the intestinal tract of humans and animals, and resistant commensal bacteria constitute a reservoir of resistance genes for potentially pathogenic bacteria (Moyaert et al., 2006).

Foods contaminated with antibiotic-resistant bacteria could be a major threat to public health via the transmission of antibiotic resistance determinants to other bacteria of human clinical significance. Escherichia coli is a candidate vehicle for such transfers which colonize the gastrointestinal tract of human as well as many animals and are also commonly found in soil, plants and water Although, most E. coli are commensal members of the normal intestinal flora, some pathogenic strains of the bacteria can cause a variety of intestinal and extra-intestinal infections (Katouli, 2010). The antibiotic selection pressure for resistance in bacteria in poultry is high leading to the high proportion of resistant bacteria in poultry fecal flora (Smith et al., 2007; Van et al., 2008).

The increasing occurrence of antibioticresistant microorganisms has raised interest to study resistance genes in E. Cole inhuman 
or/and broiler in various countries has been reported. Recently, different reports have indicated the dissemination of antibioticresistant $E$. coli strains in humans (Pires et al., 2007), in food producing animals, and in food products. These resistant bacteria could be transferred to humans through the food chain. This transfer represents a problem for public health. Therefore, this study was conducted to investigate the relationship between antibiotic resistance among $E$. coli isolates obtained from human-associated, urinary isolates and broiler chicken fecal isolates.

\section{Materials and Methods}

\section{Avian and human $E$. coli isolates}

Fresh 42 fecal samples were collected randomly from tow poultry farms in ElFayoum (located 103 kilometres southwest of Cairo), Egypt during 2014. Samples were collected over a 42-day period at 3-day intervals, kept at $6^{\circ} \mathrm{C}$ and bacteriological analyses were performed within $4 \mathrm{~h}$ of collection.

Fifty five clinical isolates of $E$. coli isolated from urine specimens from hospitalized patients at El-Kasr El-Einy hospital (Cairo) and EL-Shorta hospital (Giza), Egypt between 2014 and 2015, were also analysed in this study. The hospital serves the metropolitan area of Cairo and Giza and is located about $100 \mathrm{~km}$ from the nearest broiler farm that was investigated.

All E. coli organisms were isolated and purified on MacConkey agar (Difco laboratories, Detroit, Mich.). Colonies from each plate were then picked up and subcultured on to an eosin methyline blue (EMB) agar plate (Hi-Media, India). Presumptive $E$. coli then identified and confirmed following a series of biochemical tests included gram staining, tests for oxidase, catalese indole, Voges-Proskauer reaction, citrate, methyl red, urea hydrolysis, gelatin hydrolysis, nitrate reduction, casein hydrolysis, lactose fermentation and sugar fermentation tests.

Isolates yielding similar biochemical reactions to the standard E. coli strain ATCC 25922, were identified as $E$. coli and selected for further testing. These E. coli isolates were transferred to $2 \mathrm{ml}$ Luria broth and incubated $37^{\circ} \mathrm{C}$ for $18-24 \mathrm{~h}$. One millilitre $(1 \mathrm{ml})$ of this culture was added to $0.8 \mathrm{ml}$ of sterile $80 \%$ glycerol in a sterile tube, vortexed and stored at $-80^{\circ} \mathrm{C}$.

\section{Antimicrobial Susceptibility Test}

The antimicrobial resistance/susceptibility of each of the isolates was determined by disk diffusion test. The E. coli isolates were tested against the antibiotics of human and veterinary significance.

Thirteen commercial antibiotic discs (Mast Diagnostics, Merseyside, UK) which include: Levofloxacin (Lev) (5 $\mu \mathrm{g})$, Ceftriaxone (CRO) (30 $\mu \mathrm{g})$, Cefotaxime (CTX) $(30 \mu \mathrm{g})$, Ciprofloxacin (CIP) $(5 \mu \mathrm{g})$, Chloramphenicol (C) $(30 \mu \mathrm{g})$, Gentamycin (CN) $(10 \mu \mathrm{g})$, Ampicillin (AM) $(10 \mu \mathrm{g})$, Trimethoprim/ sulfameth (SXT) $(25 \mu \mathrm{g})$, Nitrofurantoin (F) $(300 \mu \mathrm{g})$, Aztreonam (ATM) $(30 \mu \mathrm{g}), \quad$ Amoxicillin-Sulbactam (SAM) $(20 \mu \mathrm{g})$, Tetracyciln (TE) $(30 \mu \mathrm{g})$ and Streptomycin (S) $(10 \mu \mathrm{g})$ were employed for the susceptibility testing.

After incubating the inoculated plates aerobically at $37{ }^{\circ} \mathrm{C}$ for 18 to $24 \mathrm{~h}$, the susceptibility of the $E$. coli isolates to each antimicrobial agent was measured and the results were interpreted in accordance with criteria provided by the Clinical and Laboratory Standards Institute (CLSI) interpretative charts. 


\section{DNA preparation and polymerase chain reaction}

The genomic DNA of $E$. coli was extracted using Gene JET genomic DNA extraction kit following the manufacturer protocol (Fermentas, K0721). Ten multi-resistant $E$. coli isolates (five of human and five of avian sources) were selected and screened for antibiotic resistance genes by polymerase chain reaction (PCR) using primers E. coli specific primers as previously described. Eleven antibiotic resistance genes were screened by PCR using 3 uniplex and a combination of 2 multiplex assays. Uniplex assays were designed to $\operatorname{detect}($ tetA, tetB and sull). Where, multiplex sets 1-2 were designed to detect sulI, SHV, cat1, dhfrV, OXA and TEM, cmlA, CITM, dhfrI, genes respectively (Table 1). A positive and a negative control for each PCR were included.

The uniplex PCR conditions were performed in a total volume of $50 \mu \mathrm{l}$ containing $2 \mu \mathrm{l}$ of extracted DNA with final concentration of $1.5 \mathrm{mM} \mathrm{MgCl} 2,2.5 \mu \mathrm{M}$ of each dNTP (Bioline), $0.5 \mu \mathrm{l}$ of each primer pair and $1 \mathrm{U}$ of Taq polymerase. PCR reactions for multiplex sets 1-2 were performed in a total volume of $25 \mu \mathrm{l}$ containing $2 \mu \mathrm{l}$ of extracted DNA with final concentrations of $4 \mathrm{mM}$ $\mathrm{MgCl} 2,10 \mu \mathrm{M}$ of each dNTP, $5 \mu \mathrm{l}$ of each primer pool and $1 \mathrm{U}$ of Hotstart Taq (Qiagen).

The thermal cycler (Verti, Applied Biosystem, USA) was programmed for uniplex PCR as follows: initial denaturation at $94{ }^{\circ} \mathrm{C}$ for $5 \mathrm{~min}$, with 30 cycles of denaturation at $94{ }^{\circ} \mathrm{C}$ for $30 \mathrm{~s}$, annealing at $50{ }^{\circ} \mathrm{C}$ for $30 \mathrm{~s}$, extension at $72{ }^{\circ} \mathrm{C}$ for $1 \mathrm{~min}$ and final cycle of amplification at $72{ }^{\circ} \mathrm{C}$ for 10 min. The multiplex PCR amplification conditions consisted of initial denaturation at $95{ }^{\circ} \mathrm{C}$ for $15 \mathrm{~min}$, followed by 30 cycles of denaturation at $94{ }^{\circ} \mathrm{C}$ for $30 \mathrm{~s}$, annealing at $58{ }^{\circ} \mathrm{C}$ for $30 \mathrm{~s}$, and extension at $72{ }^{\circ} \mathrm{C}$ for $1 \mathrm{~min}$ and final cycle of amplification at 72 ${ }^{\circ} \mathrm{C}$ for $10 \mathrm{~min}$. After PCRs, the reaction products were subjected to electrophoresis at $80 \mathrm{~V}, 500 \mathrm{~mA}$ for $1.5 \mathrm{~h}$ for uniplex PCRs and $2.5 \mathrm{~h}$ for multiplex PCRs in $2 \%$ agarose gels prepared in $0.5 \times$ Tris-borate-EDTA (TBE) buffer. Agarose gel stained with ethidium bromide, and visualized under UV transluminator and photographed.

\section{Results and Discussion}

Antibiotic resistance phenotypes of $E$. coli isolates

A total of 97 isolates (55 isolates of human origin and 42 isolates of animal origin) of $E$. coli were analyzed and characterized for their phenotypes of antimicrobial resistance to 13 commonly used antimicrobials. The antimicrobial susceptibility testing of all isolates towards LEV, CRO, CTX, CIP, C, CN, AM, SXT, F, ATM, SAM, TE, and S were determined by the disk diffusion method.

The antibiotic resistance profiles of the $97 \mathrm{E}$. coli isolates from different sources are shown in Table 2. All ninety seven isolates of E.coli showed multi-drug resistance (MDR) to the selected antibiotics. A relatively high resistance frequently observed against Ampicillin $78.4 \%$, Trimethoprim/sulfameth $\quad 71.1 \%$, Streptomycin $75.3 \%$, AmoxicillinSulbactam 69.1\%, Tetracyciln $65 \%$ Chloramphenicol 51.5\%, Gentamycin $51.5 \%$, Aztreonam 50.5\%, Cefotaxime $49.5 \%$ and Nitrofurantoin $38.1 \%$. On the other hand the low resistances were recorded with Levofloxacin 11.3\%, Ceftriaxone 26.8\% and Ciprofloxacin 33\%.

Antibiotic resistance pattern of E.coli isolates recovered from human recorded a 
lower frequency of resistance towards ten of the tested antibiotics than those recovered from broiler chicken (Table 2).

E.coli strains of human origin were highly resistant to Ampicillin 72.7\%, Streptomycin $69.1 \%$, Trimethoprim/sulfameth $63.6 \%$, Amoxicillin-Sulbactam (56.4\%), Tetracyciln $56.4 \%$ Cefotaxime $38.2 \%$, Chloramphenicol $34.6 \%$ and Ciprofloxacin $29.1 \%$ but less resistanc to Levofloxacin $12.7 \%$ and Ceftriaxone $25.5 \%$. However, the highest level of antibiotic resistance in broiler isolates were recorded against AmoxicillinSulbactam 85.7\%, Ampicillin 85.7\%, Streptomycin 83.3\%, Trimethoprim/ sulfameth $81 \%$, Tetracyciln $76.2 \%$ Chloramphenicol $\quad 73.8 \% \quad$ Cefotaxime 64.29\% and Ciprofloxacin 38.1 and the lowest level of resistance with Levofloxacin 9.5\% and Ceftriaxone $28.58 \%$. Although, the human isolates showed high resistance pattern to Nitrofurantoin $(43.6 \%)$ than animal isolates $(31 \%)$ there is no difference in the resistance pattern of Aztreonam and Gentamycin in both human and animal isolates.

\section{Antibiotic resistance genes in $E$. coli isolates}

Ten genes encoding resistance to antimicrobials belonging to five antimicrobial families were chosen to detect their presence within ten $E$. coli isolates (five for each human and broiler) by molecular methods (Table 3). The sul (sulfonamide), tetA (Tetracycline) and tetB (Tetracycline) resistance encoding genes were detected in all the tested isolates (100\%) but no one of tested E. coli isolates contained TEM (Beta-lactam) gene (Figure $1)$.

Both of human and broiler isolates possessed the antibiotic resistance genes
SHV (Beta-lactam) (60\%) and $d h f r V$ (Trimethoprim) (20\%) (Figure 2). Eighty percent of isolates from human were positive to OXA (Beta-lactam), (20\%) to dhfrI (Trimethoprim) and (20\%) to $\mathrm{cmlA}$ (Chloramphenicol). On the other hand, $O X A$, dhfrI and $\mathrm{cmlA}$ genes were detected in $40 \%$ of isolates from animal. The catl (Chloramphenicol) (20\%) gene was found only in the human isolates (Table 3).

Finally, characterization of the selected multidrug resistance E. coli isolates according to their phenotypic and genotypic antibiotic resistance pattern are shown in (Table 4).

The antibiotic resistance phenotype results correlated relatively with their genotypes. For example: the data showed a positive association of Sull, tetA, and tetB, genes and the resistance to sulfonamide and tetracycline agent observed in almost selected human and animal isolates. Moreover, some positive associations of SHV and OXA genes with resistance to Ampicillin antibiotic in human and animal isolates were observed. However, the other genes cmlA, cat1, dhfrI and dhfrV showed no clear correlation with their corresponding antibiotic resistance in human and animal.

In this study we surveyed the phenotypic and genotypic antimicrobial resistance in 97 of $E$. coli isolates (55 isolates of human origin and 42 isolates of animal origin). The samples collected randomly from tow poultry farms in El-Fayoum, Egypt and hospitalized patients at El-Kasr El-Einy hospital, Cairo and EL-Shorta hospital, Giza, Egypt during 2014 and 2015. Most of the broiler chickens that are sold in Cairo and Giza are brought from El-Fayoum city. Therefore, this study is necessary to find a correlation of antimicrobial resistance among human and animal E. coli isolates. 
In this study, multiple antibiotic resistance phenotypes recorded in all of the examined strains. An antibiotic resistance pattern of broiler chicken $E$. coli isolates recorded a higher frequency of resistance towards most of the tested antibiotics compared to human E. coli isolates (Table 2). This study demonstrated that, most human and avian isolates were highly resistant to Ampicillin, Streptomycin, Trimethoprim/sulfameth, Amoxicillin-Sulbactam,Tetracyciln and Chloramphenicol. These data are in agreement with those reported by. On the other hand, E. coli isolates from human and broiler chicken displayed low resistance to
Levofloxacin and intermediate resistance to Ceftriaxone and Ciprofloxacin. Johnson et $a l$., concluded that, ciprofloxacin-resistant $E$. coli may arise in the intestine of poultry from susceptible $E$. coli ancestors, be transmitted to humans via the food supply, and subsequently cause potentially life threatening infection in humans (Johnson et al., 2006). Antibiotic resistance surveillance data showed that, E. coli has high resistance for the older generation of human and veterinary antibiotics, including ampicillin, streptomycin, and tetracycline and the increasing resistance to newer antibiotics such as quinolones and cephalosporins.

Table.1 Primer sets for the amplification of the 10 antimicrobial

resistance genes in E.coli isolates

\begin{tabular}{|c|c|c|c|c|}
\hline $\begin{array}{l}\text { Gene } \\
\text { name }\end{array}$ & $\begin{array}{c}\text { Antimicrobial } \\
\text { resistance }\end{array}$ & Primers & DNA Sequence $\left(5^{\prime} \rightarrow 3^{\prime}\right)$ & $\begin{array}{c}\text { Amplified } \\
\text { product }\end{array}$ \\
\hline \multirow[t]{2}{*}{ Sull } & \multirow[t]{2}{*}{ Sulfonamide } & sull-F & TTCGGCATTCTGAATCTCAC & \multirow[t]{2}{*}{822} \\
\hline & & sull-R & ATGATCTAACCCTCGGTCTC & \\
\hline \multirow[t]{2}{*}{ tetA } & \multirow[t]{2}{*}{ Tetracycline } & tetA-F & GTGAAACCCAACATACCCC & \multirow[t]{2}{*}{887} \\
\hline & & tet $A-R$ & GAAGGCAAGCAGGATGTAG & \\
\hline \multirow[t]{2}{*}{ tetB } & \multirow[t]{2}{*}{ Tetracycline } & tet $B-F$ & CCTTATCATGCCAGTCTTGC & \multirow[t]{2}{*}{773} \\
\hline & & tet $B-R$ & ACTGCCGTTTTTTCGCC & \\
\hline \multirow[t]{2}{*}{$O X A$} & \multirow[t]{2}{*}{ Beta-lactam } & blaOXA-F & GCAGCGCCAGTGCATCAAC & \multirow[t]{2}{*}{198} \\
\hline & & blaOXA-R & CCGCATCAAATGCCATAAGTG & \\
\hline \multirow[t]{2}{*}{$S H V$} & \multirow[t]{2}{*}{ Beta-lactam } & blaSHV-F & TCGCCTGTGTATTATCTCCC & \multirow[t]{2}{*}{768} \\
\hline & & blaSHV-R & CGCAGATAAATCACCACAATG & \\
\hline \multirow[t]{2}{*}{$T E M$} & \multirow[t]{2}{*}{ Beta-lactam } & blaTEM-F & GAGTATTCAACATTTTCGT & \multirow[t]{2}{*}{698} \\
\hline & & blaTEM-R & ACCAATGCTTAATCAGTGA & \\
\hline \multirow[t]{2}{*}{$d h f r V$} & \multirow[t]{2}{*}{ Trimethoprim } & $d h f r V-F$ & CTGCAAAAGCGAAAAACGG & \multirow[t]{2}{*}{432} \\
\hline & & $d h f r V-R$ & AGCAATAGTTAATGTTTGAGCTAAAG & \\
\hline \multirow[t]{2}{*}{$d h f r I$} & \multirow[t]{2}{*}{ Trimethoprim } & $d h f r I-F$ & AAGAATGGAGTTATCGGGAATG & \multirow[t]{2}{*}{391} \\
\hline & & dhfrI-R & GGGTAAAAACTGGCCTAAAATTG & \\
\hline \multirow[t]{2}{*}{ catl } & \multirow[t]{2}{*}{ Chloramphenicol } & $C A T I-F$ & AGTTGCTCAATGTACCTATAACC & \multirow[t]{2}{*}{857} \\
\hline & & $C A T I-R$ & TTGTAATTCATTAAGCATTCTGCC & \\
\hline \multirow[t]{2}{*}{ cmlA } & \multirow[t]{2}{*}{ Chloramphenicol } & $c m l A-F$ & CCGCCACGGTGTTGTTGTTATC & \multirow[t]{2}{*}{462} \\
\hline & & $c m l A-R$ & CACCTTGCCTGCCCATCATTAG & \\
\hline
\end{tabular}


Table.2 Prevalence of antibiotic resistance among 97 E. coli isolates from human and avian sources

\begin{tabular}{|r|c|c|c|}
\hline \multirow{2}{*}{ Antibiotic } & \multicolumn{3}{|c|}{ Source of $\boldsymbol{E}$ c coli isolates and \% of resistance } \\
\cline { 2 - 4 } & $\begin{array}{c}\text { Human isolates } \\
(\mathbf{N}=\mathbf{5 5})\end{array}$ & $\begin{array}{c}\text { Broiler isolates } \\
(\mathbf{N}=\mathbf{4 2})\end{array}$ & $\begin{array}{c}\text { Total N = 97 } \\
(\mathbf{\%})\end{array}$ \\
\hline Levofloxacin (LEV) & $7(12.7 \%)$ & $4(9.5 \%)$ & $11(11.3 \%)$ \\
\hline Ceftriaxone (CRO) & $14(25.5 \%)$ & $12(28.58 \%)$ & $26(26.8 \%)$ \\
\hline Cefotaxime (CTX) & $21(38.2 \%)$ & $27(64.29 \%)$ & $48(49.5 \%)$ \\
\hline Ciprofloxacin (CIP) & $16(29.1 \%)$ & $16(38.1 \%)$ & $32(33 \%)$ \\
\hline Chloramphenicol (C) & $19(34.6 \%)$ & $31(73.8 \%)$ & $50(51.5 \%)$ \\
\hline Gentamycin (CN) & $28(50.9 \%)$ & $22(52.4 \%)$ & $50(51.5 \%)$ \\
\hline Ampicillin (AM) & $40(72.7 \%)$ & $36(85.7 \%)$ & $76(78.4 \%)$ \\
\hline Trimethoprim/sulfamethox & $35(63.6 \%)$ & $34(81 \%)$ & $69(71.1 \%)$ \\
aol (SXT) & & & $37(38.1 \%)$ \\
\hline Nitrofurantoin (F) & $24(43.6 \%)$ & $13(31 \%)$ & $49(50.5 \%)$ \\
\hline Aztreonam (ATM) & $28(50.9 \%)$ & $21(50 \%)$ & $67(69.1 \%)$ \\
\hline Amoxicillin-Sulbactam & $31(56.4 \%)$ & $36(85.7 \%)$ & $63(65 \%)$ \\
\hline (SAM) & & & $73(75.3 \%)$ \\
\hline Tetracyciln (TE) & $31(56.4 \%)$ & $32(76.2 \%)$ & \\
\hline Streptomycin (S) & $38(69.1 \%)$ & $35(83.3 \%)$ & \\
\hline & & & \\
\hline
\end{tabular}

Table.3 Summary of antibiotic resistance genes percentage in 10 selected $E$. coli isolates from human and avian sources.

\begin{tabular}{cccc}
\hline \multirow{2}{*}{$\begin{array}{c}\text { Antimicrobial } \\
\text { agent }\end{array}$} & Resistance gene & \multicolumn{2}{c}{$\begin{array}{c}\text { No. }(\%) \text { of positive isolates } \\
\text { by origin }\end{array}$} \\
\cline { 3 - 4 } & & Human isolates & Avian isolates \\
\hline Sulfonamide & sull & $5(100 \%)$ & $5(100 \%)$ \\
Tetracycline & tetA & $5(100 \%)$ & $5(100 \%)$ \\
Beta-lactam & tetB & $5(100 \%)$ & $5(100 \%)$ \\
& OXA & $4(80 \%)$ & $2(40 \%)$ \\
Trimethoprim & SHV & $3(60 \%)$ & $3(60 \%)$ \\
& TEM & $0(0 \%)$ & $0(0 \%)$ \\
Chloramphenicol & $d h f r V$ & $1(20 \%)$ & $1(20 \%)$ \\
& $d h f r I$ & $1(20 \%)$ & $2(40 \%)$ \\
& $c a t 1$ & $1(20 \%)$ & $0(0 \%)$ \\
& $c m l A$ & $1(20 \%)$ & $2(40 \%)$ \\
\hline
\end{tabular}


Table.4 Phenotypic and genotypic characterization of antimicrobial resistance among 10 selected $E$. coli isolates

\begin{tabular}{|c|c|c|c|}
\hline \multirow{2}{*}{$\begin{array}{l}\text { Isolate } \\
\text { number }\end{array}$} & \multirow[t]{2}{*}{ source } & \multicolumn{2}{|c|}{ Antibiotic resistance characteristics } \\
\hline & & Resistance pattern (Phenotypic) & $\begin{array}{l}\text { Resistance gene } \\
\text { (Genotypic) }\end{array}$ \\
\hline $1-7$ & \multirow[t]{5}{*}{ human } & LEV CIP C AM SAM TE & $\begin{array}{r}\text { Sull, tetA, tetB, SHV, } \\
\text { OXA, cmlA }\end{array}$ \\
\hline $2-9$ & & CTX AM SXT ATM SAM S & Sull, tetA, tetB, catl, dhfrI \\
\hline $3-10$ & & CIP AM SXT TE & Sull, tetA, tetB, SHV, OXA \\
\hline $4-15$ & & $\begin{array}{r}\text { LEV CRO CTX CIP C CN AM SXT } \\
\text { SAM TE S }\end{array}$ & $\begin{array}{r}\text { Sull, tetA, tetB, SHV, } \\
\text { dhfrV, OXA }\end{array}$ \\
\hline $5-16$ & & C CN AM SXT ATM SAM TE S & Sull, tetA, tetB, OXA \\
\hline $6-23$ & \multirow[t]{5}{*}{ brolier } & CRO CTX CIP C AM SXT SAM TE S & Sull, tetA, tetB, SHV, cmlA, \\
\hline $7-20$ & & C AM SXT F SAM TE & Sull, tetA, tetB, SHV \\
\hline $8-21$ & & CIP C CN AM SXT SAM TE S & Sull, tetA, tetB, OXA \\
\hline $9-25$ & & CTX CIP C CN AM SXT SAM TE S & $\begin{array}{r}\text { Sull, tetA, tetB, SHV, } \\
\text { OXA, dhfrI }\end{array}$ \\
\hline $10-24$ & & C AM SAM TE S & $\begin{array}{r}\text { Sull, tetA, tetB, dhfrV, } \\
\text { cmlA, dhfrI }\end{array}$ \\
\hline
\end{tabular}

Fig.1 Agarose gel electrophoresis of uniplex PCR amplified products of sulI (A), tetA (B) and tetB (C) antimicrobial resistance genes. Lane M: DNA molecular size marker, lane St.: standard E. coli strain ATCC 25922, lanes (3-7) 7,9,10,15 and 16 are human E. coli isolates, lanes (8-12) 23, 24, 25, 20 and 21 are broilers $E$. coli isolates and lane (13) -ve for negative control. The size in base pairs (bp) of each PCR product is indicated on the right of the bands.

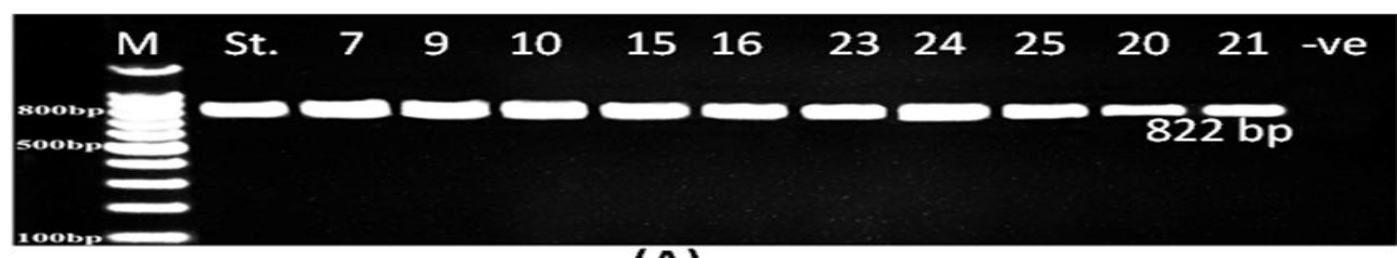

(A)

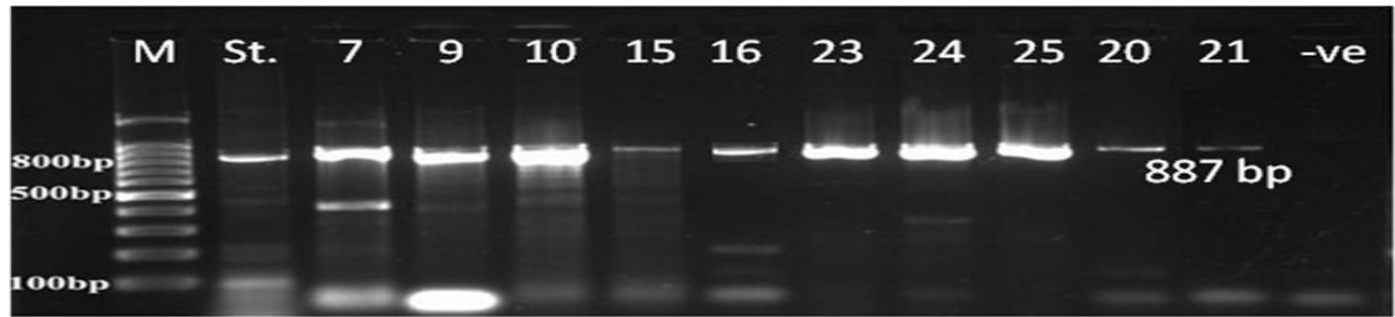

(B)

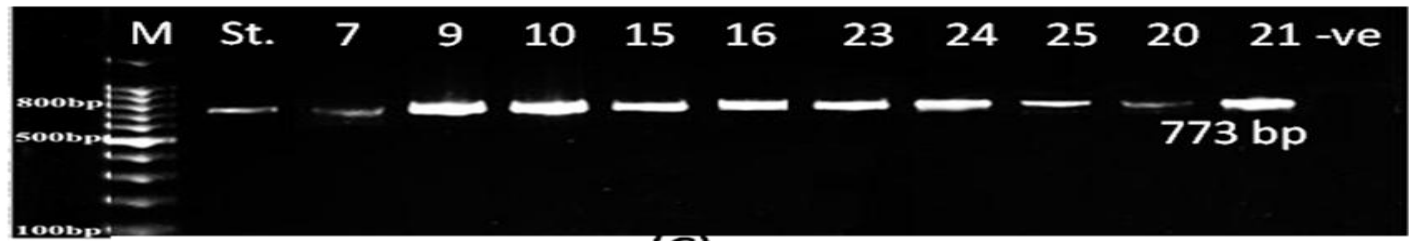

(C) 
Fig.2 Agarose gel electrophoresis of multiplex PCR amplified products of group A: (blaSHV=768; CATI=547; $\operatorname{dhfrV}=432 ;$ blaOXA=198) and group B: (dhfr1=391bp; $\mathrm{CM} 1 \mathrm{~A}=698$; blaTEM =857) antimicrobial resistance genes. Lane M: DNA molecular size marker, lane St.: standard E. coli strain ATCC 25922, lanes 7,9,10,15 and 16 are human E. coli isolates, lanes 23, 24, 25, 20 and 21 are broilers E. coli isolates and lane-ve for negative control. The size in base pairs (bp) of each PCR product is indicated on the left of the bands.
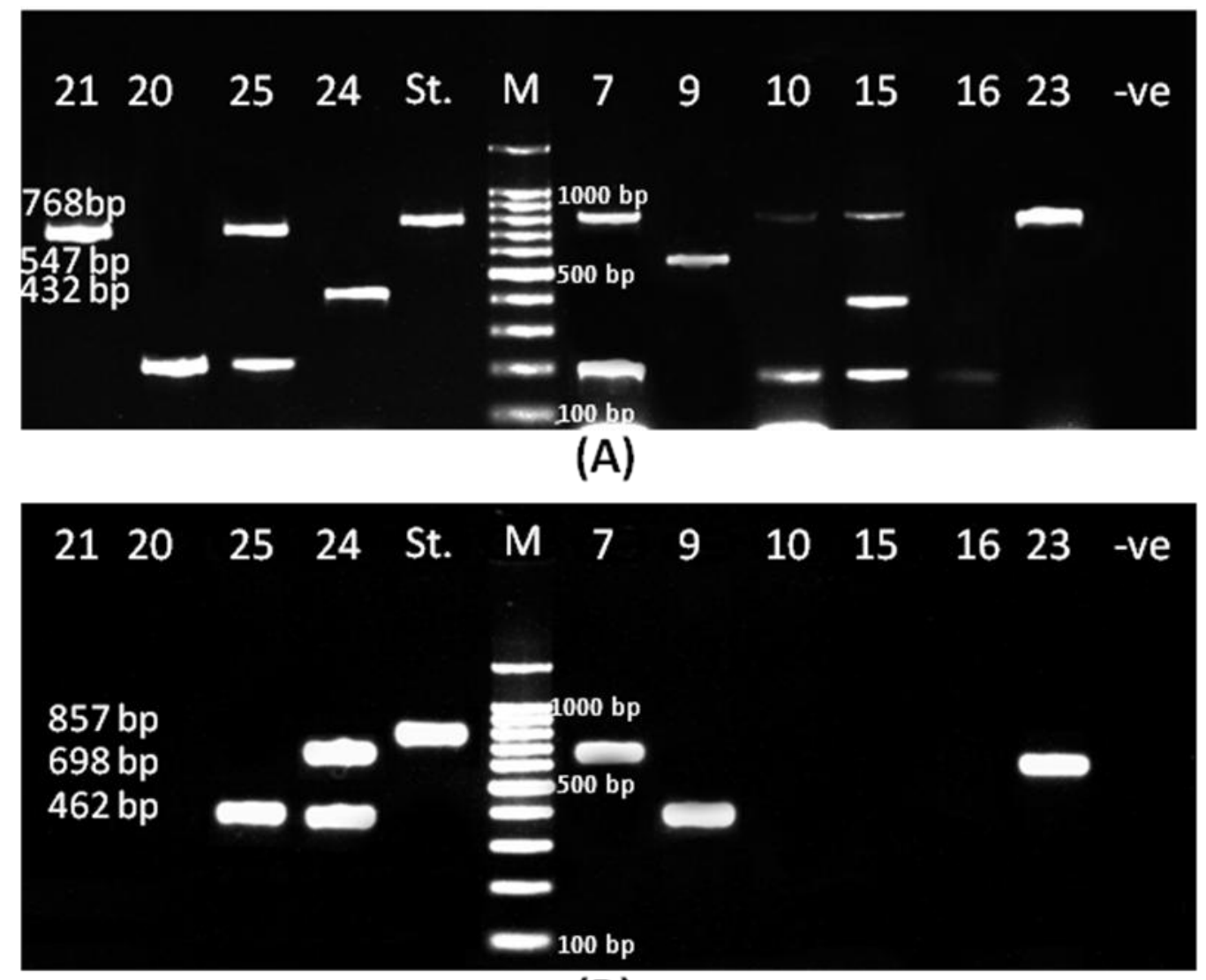

(B)

Furthermore, Our study demonstrated that, resistance to ampicillin, streptomycin, trimethoprim-sulphamethoxazole,

Amoxicillin-Sulbactam, tetracycline and chromaphenicol was higher $(50-86 \%$.) and in agreement with other clinical studies (Bhowmick et al., 2004), as well as to poultry studies (Soufi et al., 2011; Persoons et al., 2010).

Antibiotic usage is considered the most important factor promoting the emergence, selection and dissemination of antibioticresistant microorganisms in both veterinary and human medicine. The significance of the animal reservoir for the occurrence of urinary tract infection due to antimicrobialresistant $E$. coli in humans is unknown, but studies have shown links between the animal reservoir and illness in human.

A substantial proportion of most of the old antibiotic and the recently reported plasmidmediated ciprofloxacin resistances are shown to transfer horizontally (Hawkey et al., 2009). Therefore, this mode of transmission is possible. Other potential modes of transmission include direct contact with live animals, their environment or exposure to contaminated water sources (Aarestrup, 2006). 
High resistance was observed with tetracycline from both human and animal sources, due to the location of tetracycline genes on mobile elements (Roberts, 2003). The tet $A$ and tet $B$ genes as well as sull detected in all human and avian $E$. coli isolates. These three genes were reported to be predominant in E. coli isolates from both human and animal sources, this confirms the increasing numbers of reports detailing circulation and amplification of antimicrobial resistance genes especially tetracycline resistance in the environment (Xibiao et al., 2011; Mostafa et al., 2014).

Although some resistance genes, such as beta-lactamase blaSHV, and trimethoprim $d h f r V$ were equally represented in the animal and human isolates, differences in the distributions of beta-lactamase blaOXA, trimethoprim $d h f r I$, and chloramphenicol (catI, and cmlA) resistance genes were observed between the animal and the human isolates. In contrast, other beta-lactamase genes such as TEM-type and was not detected in any isolates in this study. Our findings are similar to previous findings in other countries showing that E. coli strains from human and animal origins had blactam genes in Egypt in Tunis (Ben Sallem et al., 2012). E. coli isolates from humans and animals have been previously reported in Netherlands, suggesting a likely transmission of ESBL- E. coli isolates from poultry to human, most probably via the food chain. It is also demonstrated by different authors that, E.coli containing trimethoprim (dhfrI and $d h f r V$ ) and chloramphenicol (catI, and cmlA) resistance genes was detected in human (Maynard et al., 2004).

It could be concluded that, $E$. coli isolates from both human and broiler chickens were multi-drug resistant to commonly used antibiotics. This multi-drug resistant was relatively higher in $E$. coli strains from broilers compared to those from clinical origin. Our data propose that, antimicrobial use in clinical medicine and in agriculture was important in the selection and of antimicrobial-resistant genotypes and phenotypes. These findings support the need for more attention to improve farming practices that can lower the carriage of antibiotic resistance genes and thereby decrease the likelihood of horizontal gene transfers of these genes to other bacterial strains in the food chain.

\section{Conflict of Interest}

We declare that we have no conflict of interest.

\section{Acknowledgements}

Authors are grateful to the laboratory staff of El-Kasr El-Einy hospital, Cairo and ELShorta hospital, Giza, Egypt.

\section{References}

Aarestrup, F.M. 2006. The origin, evolution, and local and global dissemination of antimicrobial resistance. In: Aarestrup FM editor. Antimicrobial Resistancein Bacteria of Animal Origin. ASM Press, Washington DC: USA: 339-360.

Ahmed, S.H., Daef, E.A., Badary MS, Mahmoud, M.A, Abd-Elsayed AA. Nosocomial blood stream infection in intensive care units at Assiut University Hospitals (Upper Egypt) with special reference to extendedspectrum-3-lactamase producing organisms. BMC Res Notes, 2:76.

Aly, M.E.A., Essam, T.M., Amin, M.A. 2012. Antibiotic Resistance Profile of E. coli Strains Isolated from Clinical Specimens and Food Samples in 
Egypt. Int. J. Microbiol. Res., 3: 176182.

Authier, S., Paquette, D., Labrecque, O., Messier, S. 2006. Comparison of susceptibility to antimicrobials of bacteria isolates from companion animals in a veterinary diagnostic laboratory in Canada between 2 time points 10 years apart. Can. Vet. J., 47: 774-778.

Ben Sallem, R., Ben Slama, K., Estepa, V., Jouini, A., Gharsa, H. 2012. Prevalence and characterisatin of extended-spectrum beta-lactamase (ESBL)-producing Escherichia coli isolates in healthy volunteers in Tunisia. Eur. J. Clin. Microbiol. Infect. Dis., 31: 1511- 1516.

Bhowmick, B.K., Rashid, H. 2004. Prevalence and Antibiotic susceptibility of E. coli isolates from Urinary Tract Infection (UTI) in Bangladesh. Pak. J. Biol. Sci., 7(5): 717-720.

Cabello, F.C. 2006. Heavy use of prophylactic antibiotics in aquaculture: a growing problem for human and animal health and for the environment. Environ. Microbiol., 8: 1137-1144.

Clinical and Laboratory Standards Institute. Performance standards for antimicrobial susceptibility testing: 20th informational supplement. CLSI doc M100-S21. Wayne, Pa. 2011.

Davies, J., Davies, D. 2010. Origins and evolution of antibiotic resistance. Microbiol. Mol. Biol. Rev., 74: 417-33.

Davison, J. 1999. Genetic exchange between bacteria in the environment. Plasmid, 42: 73-91.

Ferber, D. 2003. Antibiotic resistance: WHO advises kicking the livestock antibiotic habit. Sci., 301, 1027.

Gai, W., Wang, J., Wang, J., Cui, Z., Qu, Z., Cui, J., et al. 2015. Molecular classifiation and drug resistance analysis of Escherichia coli isolated from poultry in China. Int. J. Clin. Exp. Med., 8(1):836-844.

Greenwood, D., Finch, R., Davey, P., Wilcox, M. 2006. Antimicrobial Chemotherapy. 5th ed. by Oxf. Univ. Pre.: Inc New York.

Guerra, B., Junker, E., Schroeter, A., Malorny, B., Lehmann S, Helmuth R. 2003. Phenotypic and genotypic characterization of antimicrobial resistance in German Escherichia coli isolates from cattle, swine and poultry. J Antimicrob. Chemoth., 52: 489-492.

Hammami, S., Saidani, M., Ferjeni, S., Aissa, I, Slim A. 2013. Characterizatin of extended spectrum B-lactamaseproducing Escherichia coli in community-acquired urinary tract infectins in Tunisia. Microb. Drug Resist., 19: 231-236.

Hawkey, P.M., Jones, A.M. 2009. The changing epidemiology of resistance. J. Antimicrob. Chemoth., 64: 3-10.

Jakobsen, L., Kurbasic, A., SkjøtRasmussen, L., Ejrnæs K, Porsbo L, Pedersen, K., et al. Escherichia coli Isolates from Broiler Chicken Meat, Broiler Chickens, Pork, and Pigs Share Phylogroups and Antimicrobial Resistance with Community-Dwelling Humans and Patients with Urinary Tract Infection. Foodborne Pathog Dis., 7: 537-547.

Johnson, J.R., Kuskowski, M.A., Menard, M, Gajewski A, Xercavins M, Garau, J. Similarity between human and chicken Escherichia coli isolates in relation to ciprofloxacin resistance status. J. Infect. Dis., 194: 71-8.

Johnson, J.R., Sannes, M.R., Croy, C., Johnston, B., Clabots, C., Kuskowski, M.A., et al. 2007. Antimicrobial drugresistant Escherichia coli from humans and poultry products, Minnesota and 
Wisconsin, 2002-2004. Emerg. Infect. Dis., 13: 838-846.

Katouli, M. 2010. Population structure of gut Escherichia coli and its role in development of extra-intestinal infections. Iran J Microbiol., 2: 59-72.

Katouli, M. 2010. Population structure of gut Escherichia coli and its role in development of extra-intestinal infections. Iran J. Microbiol., 2: 5972.

Kilani, H., Abbassi, M.S., Ferjani, S., Mansouri R, Sghaier S, Ben Salem R, et al. 2015. Occurrence of bla CTX$\mathrm{M}-1, q n r \mathrm{~B} 1$ and virulence genes in avian ESBL-producing Escherichia coli isolates from Tunisia. Front. Cell. Infect. Microbiol., 5:38.

Koneman, E.W.A.S., Janda, W.M., Schreckenberger, P., Winn, W.C. 1997. Antimicrobial Resistance. Color Atlas and Text book of Diagnostic Microbiology. 5th ed. USA Philadelphia, 798-800.

Kumarasamy, K.K., Toleman, M.A., Walsh, T.R., Bagaria, J., Butt, F., Balakrishnan, R. 2010. Emergence of a new antibiotic resistance mechanism in India, Pakistan, and the UK: a molecular, biological, and epidemiological study. Lancet Infect. Dis., 10: 597-602.

Maynard, C., Bekal, S., Sanschagrin, F., Levesque, R.C., Brousseau, R., Masson, L., et al. 2004. Heterogeneity among Virulence and Antimicrobial Resistance Gene Profiles of Extraintestinal Escherichia coli Isolates of Animal and Human Origin. J. Clin. Microbiol., 42: 5444-5452.

Meyer, E., Lunke, C., Kist M. Antimicrobial Resistance in Escherichia coli Strains Isolated from Food, Animals and Humans in Germany. Infect., 36: 5961.
Mostafa, A.M., Nasef, S.A., El-Hariri, M., and Refai, M. Detection of Plasmid Mediated Quinolone and $\beta$-lactam Resistant Genes in Escherichia coli Isolates from Diseased Poultry in Egypt. Int. J. Adv. Res., 2: 758-769.

Moyaert, H., De Graef, E.M., Haesebrouck, F., Decostere, A. 2006. Acquired antimicrobial resistance in the intestinal microbiota of diverse cat populations. Res. Vet. Sci., 81: 1-7.

Nikolich, M.P., Hong, G., Shoemaker, N.B., Slayers, A.A. 1994. Evidence for natural horizontal transfer of tet $Q$ between bacteria that normally colonize humans and bacteria that normally colonize livestock. Appl. Environ. Microbiol., 60: 3255-3260.

Okeke, I.N., Edelman, R. 2001. Dissemination of antibiotic-resistant bacteria across geographic borders. Clin. Infect. Dis., 33: 364-9.

Overdevest, I., Willemsen, I., Rijnsburger, M., Eustace, A., Xu, L., Hawkey, P. 2011. Extended-spectrum $\beta$-lactamase genes of Escherichia coli in chicken meat and humans, The Netherlands. Emerg. Infect. Dis., 17: 1216-1222.

Ozaki, H., Esaki, H., Takemoto, K. 2012. Antimicrobial resistance in fecal Escherichia coli isolated from growing chickens on commercial broiler farms. Vet. Microbiol., 150: 132-9.

Persoons, D., Dewulf, J., Smet A. Prevalence and persistence of antimicrobial resistance in broiler indicator bacteria. Microbiol Drug Resist., 16: 67-74.

Pires, M.C.S., Frota, K.S., Martins Junior, P.O. 2001. Prevalence and bacterial susceptibility of community acquired urinary tract infection in University Hospital of Brasília, 2001 to 2005. Rev. Soc. Bras. Med. Trop., 40: 643647. 
Ramchandani, M., Manges, A.R., DebRoy, C., Smith, S.P., Johnson, J.R., Riley, L.W. 2005. Possible animal origin of human-associated, multidrug-resistant, uropathogenic Escherichia coli. Clin. Infect. Dis., 40: 251-7.

Roberts, M.C. 2003. Tetracycline therapy: update. Clin. Infect. Dis., 36: 462-467.

Smith, J.L., Drum, D.J.V., Dai, Y., Kim, J.M., Sanchez, S., Maurer, J.J. 2007. Impact of Antimicrobial Usage on Antimicrobial Resistance in Commensal Escherichia coli Strains Colonizing Broiler Chickens. Appl. and Environ. Microbiol., 73: 14041414

Sørum, H., Sunde, M. 2001. Resistance to antibiotics in the normal flora of animals. Vet. Res., 32: 227-241.

Soufi, L., Saenz, Y., Vinue, L., Abbassi, M.S, Ruiz E, Zarazaga M. 2011. Escherichia coli of poultry food origin as reservoir of sulphonamide resistance genes and integrons. Int. J. Food Microbiol., 144:497-502.

Stecher, B., HardtW. 2010. The role of microbiota in infectious disease. Trends Microbiol., 16:107-114.

Sunde, M., Nordstrom, M. 2006. The prevalence of, associations between and conjugal transfer of antibiotic resistance genes in Escherichia coli isolated from Norwegian meat and meat products. J. Antimicrob. Chemoth., 58: 741-747.

Tadesse, D.A., Zhao, S., Tong, E., Ayers, S., Singh, A., Bartholomew, J. 2012. Antimicrobial drug resistance in Escherichia coli from humans and food animals, United States, 19502002. Emerg. Infect. Dis., 18: 741749.

Van, T.T.H., Chin, J., Chapman, T., Tran, L.T., Colo, P.J. 2008. Safety of raw meat and shellfish in Vietnam: an analysis of Escherichia coli isolations for antibiotic resistance and virulence genes. Int. J. Food Microbiol., 124:217-223.

Werner, G., Hammerum, A.M., Coque, T.M., Hope, R., Hryniewicz, W., Johnson, A. Emergence and spread of vancomycin resistance among enterococci in Europe, Euro Surveill. 200813 Available online: http://www.eurosurveillance.org/View Article.aspx?ArticleId=19046.

World Health Organisation (WHO). 2015. Antimicrobial resistance. Avaliable at http://www.who.int/mediacentre/ factsheets/fs194/en/. Accessed 29 May 2015.

Xibiao, T,. Chen, T., Xuan, Z., Zhanqin, Z., Xin, X., Bin, W. 2011. Antimicrobial resistances of extraintestinal pathogenic Escherichia coli isolates from swine in China. Microbia Pathogenes, 50: 207-212.

\section{How to cite this article:}

Mohamed Elmahdy Shehata, Gamal Mohamed EL-Sherbiny, Amira Hussainy Mohamed and Hesham Mohamed Shafik. 2016. Molecular and Phenotypic Characterization of Some Antimicrobial Resistance Genes in Escherichia coli Isolated from Human and Broiler Chickens. Int.J.Curr.Microbiol.App.Sci. 5(12): 953-965. doi: http://dx.doi.org/10.20546/ijcmas.2016.512.104 